\title{
Not Just Add-Gender-\&-Stir: Feminist Archaeology and the Use of Feminist and Evolutionary Biological Approaches to Patriarchy
}

\author{
Fiona Handley \\ Institute of Archaeology, UCL
}

\begin{abstract}
The relationship between men and women is of interest to many parties concerned with human behaviour. Feminists and evolutionary biologists are two such groups that have examined gender issues from different positions and have reached frequently opposing conclusions. These divisions have only recently started to be breached as common ground is investigated. This paper examines some of these issues, discusses the implications this rapprochement could have on feminist archaeology, and suggests a path for the development of a social archaeology that traverses the artificial barriers between 'nature' and 'culture'.
\end{abstract}

\section{Introduction}

The analysis of gender relationships has been the focus of investigations from many parties interested in human behaviour. There have been many different propositions about the nature of relationships between men and women; feminists have taken a particular interest in the extent and style of women's oppression within a cultural context, whilst evolutionary biologists have traced the roots of oppression back to the differing reproductive strategies of males and females. The different agendas of these two disciplines mean that they have traditionally been positioned against one another in a perpetuation of the debate on the causal power of nature against culture. Meanwhile, feminist archaeologists have only recently begun a serious investigation of gender as an important structuring social relationship as part of the development of a social archaeology which began in the 1980's, since when archaeology has emphasised culture as the dominant influence over of human behaviour.

In this paper I examine one aspect of this gender relationship, the control of women by men, from the angles of evolutionary biology, feminism and feminist archaeology. The interest shown by all three disciplinary areas in gender relationships would suggest that they have much to contribute to a more sophisticated understanding of men and women in the past, however I point out that a feminist archaeology has ignored the notion of control over women that both a feminist and a biological perspective call for, and conclude that archaeology would be an ideal discipline to traverse the artificial barriers between 'biology' and 'culture' that the rejection of biology by feminism has depended upon.

\section{Feminisms and Feminists}

Feminism is a group of theories or perspectives that attempt to describe women's oppression, its causes and consequences, and prescribe strategies for women's liberation (Tong 1989: 1). The focal point of these attacks has been the patriarchal system which defines a set of power hierarchies which position men as dominant over women. From this small base has sprouted the multitude of feminisms whose various perspectives and resulting arguments have led to a clouding of what the feminist agenda is. Whilst male oppression was the original focal point for feminist 
activity, feminists now embrace a more nuanced impression of patriarchy through a realisation of the breadth of women's experiences in different societies. However, like so many other structures defined by men, patriarchy's manifestations are much more various than previously presented. This debate is complicated by differing notions and uses of the category 'patriarchy'; as Rosalind Coward points out "variously, patriarchal relations describe the oppression of all women by all men, ... a particular kind of kinship structure, or finally a residual ideology of male dominance" (Coward 1983: 270), whilst Patricia Gowaty considers that "patriarchal ideology serves the interests of some men at the expense of most women" (Gowaty 1992: 236).

However, whilst most feminists now reject a universalization of 'woman' and 'patriarchy', women have what Helene Cixous describes as "in common" (Cixous 1991: 224), a mutuality of experience that includes a power relation with men which focuses on the femaleness of their bodies. Therefore an investigation into the ways societies have moulded women's lives, bodies and experiences forms the basis of most feminist interest, and concomitant to this is an appraisal of how the varying degrees of male domination in societies has affected women. The notion that in a patriarchal society a woman understands herself through knowledge structures created by men (for their own ends), leads to the proposition that to understand themselves in their own terms women must be completely liberated from the patriarchal regime. However, the modern Western world, being patriarchal, leaves little or no room for this kind of exploration. Instead, women must look to other cultures to find models of liberation, a search which has had mixed results (see Ortner 1974, Rosaldo 1974, Daly 1978, Jaggar 1983, Caplan 1987, Strathern 1988). In particular this has led to an interest in societies which existed before patriarchy came into being, an enticing quest because as Judith Butler points out, by searching for its origins "patriarchy could be shown to have a beginning and, hence be subject to an end" (Butler 1990: 35). But defining a pre-patriarchal matriarchy also suggests a progression 'towards' patriarchy, an uncomfortable situation considering nineteenth century societal models which positioned matriarchal societies as a primitive stage in human evolution.

If the extent to which men control women in different societies is undecided, the feminist agenda still requires an enquiry into its causes. Whilst feminists have described the variations between societies in cultural terms, debates that explain the general trend towards men controlling women run into problems of essentialism as different feminists disagree as to the extent to which male and female 'characteristics' are innate. This is further complicated by feminists wariness of accepting a biological explanation for the relationship between the sexes, because the political nature of feminism requires that it is the cultural practices that form or contribute to gender hierarchies which must be targeted and changed. This, combined with the contribution from science, especially biological and medical science, to the oppression of women means that many feminists are suspicious of attempts by biology to contribute to any discussion of women. However, whilst this reluctance is understandable, it ignores the role of feminists working in science, and the contribution science can make to the wider aims of feminism. 


\begin{abstract}
"Feminists... seem haunted by an unrealistic fear: What if the social Darwinists are right when they assert that women have never been the social equals of men? I think this has retarded inquiry into the question of women's position. Instead of tackling the problem head on, many have often found it easier to make end runs or apologies, conceding that women are subordinate but reasoning that culture, not biology, has put us in the position... these may be consoling or inspirational thoughts, but they are not scientifically convincing or helpful, for they do not speak to what it is in culture that supposedly demands women's subordination" (Sacks 1979: 5).
\end{abstract}

Karen Sacks wrote this twenty years ago when the women's movement was attacked by sociobiologists who asserted that patriarchy, along with other human behaviour, had evolved to maximise the reproductive fitness of individuals, thus making feminism redundant, even unnatural. Whilst sociobiology's simplistic transference of models of animal behaviour onto humans has since become more sophisticated, its legacy means that feminists, alongside many other groups who have struggled against oppression, remain extremely suspicious of both evolutionary schemes and sociobiological models.

What concerned feminists was that by tracing the cause of female oppression to genes, not only were inequalities in gender relationships naturalised through ancestry, but the responsibility of change was removed from any one individual's hands. What's more, feminists were well aware that claims of the 'naturalness' of patriarchy were created by the self-fulfilling ideology of the institution, yet were being supported through research by sociobiologists. As Kate Millet pointed out "patriarchy has a... tenacious or powerful hold through its successful habit of passing itself off as nature" (Millet 1971: 58 Sexual Politics, cited in Sayers 1982:1).

However, according to Smuts (1995) and Gowaty (1992, 1997), feminist theory and evolutionary biology need a closer integration because they are both concerned with the same basic issues. Feminist theory is concerned with issues of power, as is evolutionary biology when applied to social behaviour. More centrally, evolutionary theory often focuses upon sexual behaviour and reproduction, whilst many feminists see the control of female sexuality as at the heart of patriarchy. So by "addressing the question of the origins of the male desire for control of female sexuality" (Smuts 1995: 2), evolutionary biology, according to Smuts, is adding an important dimension to the discussion of patriarchy.

The point of departure for evolutionary biologists is in the necessarily differing reproductive strategies of males and females caused by their respective biologies. Female mammals invest a large amount of energy in the gestation and lactation of just a few infants, whilst males can reproduce simply by fertilising a female, and can continue fertilising other females without any further commitment in time or energy to the first female. Males are therefore more likely to mate with any female that is fertile, whilst females are more likely to choose partners who will provide protection, resources and parental care. The reproductive success for females is therefore limited by the physiological processes of gestation, whilst the limiting resource for males is access to females. This difference "creates a widespread conflict of interest between the sexes" (Smuts 1995: 5). Smuts has undertaken a detailed study of sexual coercion 
in non-human primates' leading to the conclusion that "males sometimes employ coercion to resolve conflicts in their favor" (Smuts 1995: 5) but are not always successful because female primates have their own strategies of resistance. Although the extent of male power over.. females differs widely in different primate communities, male coercion seems worse in primate groups where social support between females is weaker. It seems that females who resist male coercion best are those who have "supportive social relationships, sometimes with other females, sometimes with males" (Smuts 1995: 10), while resistance is worst in females separated from relatives and friends. Smuts understands this as a starting point for a comparison between non-human male primates' coercion of females and men's ability to control female sexuality. She accepts that this does not completely explain patriarchy as human societies exhibit a much wider variation in extent of male coercion than seen in non-human primates, but defends her stance as the "midpoint of a broad distribution of characteristics" (Smuts 1995: 21). But if patriarchy has as one of its starting points male control of female reproduction, this appears to implicate biological rather than cultural explanatory factors. Both Smuts (1995) and Gowaty (1992) are at pains to point out that an evolutionary perspective is not necessarily genetically deterministic, and Smuts's argument centres on the notion that biology does not dictate behaviour, but rather works in conjunction with the environment and culture, and cannot be singled out as the determinant of the most 'normal' behaviour. She argues that because natural selection works on variation rather than norms, then a variety of styles of behaviour would be selected from within certain limiting factors which are defined by biological, ecological and cultural constraints. Gowaty furthers this argument by demanding a new emphasis on female choice, because "in response to male efforts to control females' reproduction, females should be selected to resist male control" (Gowaty 1992: 231).

\section{Dialogues but no Discussion: Archaeology/Feminism/Biology}

So whilst feminism and evolutionary biology are only very recently beginning a tentative dialogue; archaeology's relationship with both of them has been rather inconsistent. Whilst biology had its greatest influence through the ecology-based processual archaeology, and continues to have a major role in forager and hominid studies, feminism's influence has been more recent and more oblique, and has found its position in influencing gender archaeology within a more general social archaeology. Hence there has been very little contact between these two theoretical influences within archaeology, as social archaeology is constructed partially through a reaction against environmental approaches.

Whilst the aftermath of Engendering. Archaeology (Gero and Conkey 1991) has inspired a generation of gender/feminist archaeologists, the political activity which a feminist archaeology presumes seems to have been slow to appear. Whilst various studies have concentrated on revealing the importance of past female archaeologists, on revealing women in past societies and reassessing male bias within the practice and teaching of the discipline generally, (see Balme and Beck 1995; Claassen 1992, 1994; Claassen and Joyce 1997; du Cros and Smith 1993, Moore and Scott 1997; Walde and Willows 1991; Wright 1996) few feminist archaeologists have taken on an explicitly feminist research agenda. But, as several authors have pointed out (e.g. Conkey and Gero 1997, Dobres 1995), whilst calls to expose bias in the discipline and refocus on women and gender in the archaeological record have been successful, 
the more ambitious plans for a feminist epistemology are harder to define. Instead, feminists' agendas have variously called for multiple interpretations (Conkey and Gero 1997), for a focus on agency and the individual (Nelson 1997), for a development of complex views of bodies (Yates 1993, Meskell 1996) and for new styles of teaching (Conkey and Tringham 1996). But little has been said on the subject central to a feminist agenda; that of the control of women's lives by men. Instead, the feminist debate has been dominated by archaeology's reaction to feminists from outside the discipline using archaeological evidence to suggest that prehistoric European society was matriarchal.

\section{Matriarchies and Marking Feminist Territory}

The notion of "the Goddess", as defined in a series of popular books by the Californian archaeologist Maria Gimbutas, suggests an alternative to patriarchy that has attracted the attention of both feminists and archaeologists. She suggests that the societies of 'Old Europe' were matriarchal, peaceful, egalitarian and culturally homogenous, and practised a religion that worshipped female qualities embodied in art such as figurines (Gimbutas 1982, 1989, 1991). This societal equilibrium was disturbed by Indo-European invaders who introduced patriarchy, and set the seed for the oppression of women today. This notion of a pre-patriarchal matriarchal society is attractive to many feminists for the reasons I discussed earlier. However, feminist archaeologists are critical of Gimbutas on several counts (Conkey and Tringham 1995; Meskell 1995; Talalay 1994). Firstly, Gimbutas collapses the European Palaeolithic and Neolithic into one cultural block and presents simplistic interpretations of material culture such as figurines. Secondly, Gimbutas's matriarchy does little more than reverse the patriarchal system by re-valuing female 'characteristics' as positive.

The result of the Goddess debate seems to be a great scepticism towards the role of feminist theory in archaeology. Whilst Conkey and Tringham (1995) argued strongly for a feminist archaeology that could be archaeological viable, this approach has been downgraded from a feminist to a feminist-inspired agenda (Hill 1998: 113). Hill is concerned that a feminist approach raises no questions about the past but instead involves a search and inevitable discovery of matriarchal societies. She perceives feminism as exerting a subtle, and dangerous, pressure on archaeology, stating "the distinction between political commitments and archaeological research ought to be maintained... it is critical that the past not be used to validate the political present ... or serve as a form of psychotherapy at the expense of the archaeological record" (Hill 1998: 113). This view underestimates the diversity of opinions within feminism concerning the essential nature of women, and also presumes that feminists wil] ignore an argument based on archaeological evidence. Rather, feminists have had to use literature such as Gimbutas's because there is no other feminist prehistory that they can draw upon.

\section{No Matriarchies, No Patriarchies: Archaeology's Position}

Feminist archaeologists reject Gimbutas's matriarchy, and are equally reticent about suggesting a scenario of patriarchy. Instead it seems that "variable, dynamic, and historically specific gender roles, relations, ideologies, and identities" (Conkey and Tringham 1995: 226) replace any tangible notion of gender relationships in the past, a stance which is absorbed from feminist anthropology (see Harvey 1998). An 
understanding of gender that moves away from stereotypes is certainly needed, but does that mean that gender relationships were completely fluid in the past? But further to this, what would a feminist epistemology demand we ask of the archaeological record? Whilst Alison Wylie claims that "those categorised as women under existing sex/gender conventions tend to be, in varying ways and to different degrees, systematically disadvantaged as women, compared to men who otherwise share their status or social location" (Wylie 1997: 33), an analysis of this pervasive oppression of women is not reflected in feminist archaeology. Wylie refers to existing sex/gender conventions: the fact that these are not universal does not stop feminists being concerned with the status of women in non-Western countries, because the "in common" shared by all women necessitates an interest. The question arises therefore as to whether this "in common". should be looked for in lives of past women, or does approaching the past with a critical attitude to the relationship between men and women mean we are destined to repeat the stereotyping of roles of a previous generation and universalise patriarchy? Could we combine evolutionary biology with a feminist enquiry to ask questions of the archaeological record that do not presume male control over women, but could allow this scenario to appear? This requires a sophisticated argument which does not make the past subject to today's political agenda, but accepts that an investigation into women should neither end at a reiteration of the importance of women's activities nor shy away from talking about oppression of women by men for fear of universalising the principle.

How can we incorporate this sophisticated feminism into archaeological questions? Feminist archaeologists have focused on two episodes at which gender becomes critical; the development of agriculture (e.g. Bender 1989) and the formation of the state (e.g. Nelson 1998). For example, in discussing the central importance of the role of women as gatherers in the development of agriculture in North America, Patty Jo Watson and Mary Kennedy describe how female knowledge of plants and the environment allowed agriculture to begin, in other words, women were the instigators of huge social, economic and technical change in the area (Watson and Kennedy 1998: 181). This is exciting but why isn't the analysis pushed further to ask why the involvement in this wealth and status-creating enterprise did not result in evidence for greater female power, when we know that women have the organisational and innovative skills to do it? Could it be because men appropriated their skills and used these resources in maintaining a male power structure? Why do feminist archaeologists have nothing to say about this?

Gender archaeology has uncovered evidence to show the importance of women's activities in past societies, but if this didn't result in changes in women's status we can either say women were incapable of gaining powerful roles, or that they were excluded from certain roles because of their gender, or they had equally powerful roles that have been obscured by the archaeological record and the discipline of archaeology. Feminist archaeologists, whilst rejecting the first scenario, seem unable or unwilling to embrace the second, and take comfort in the third. This is because the investigation into gender seems to have ignored the relational nature of the structure, which presumes an aspect of control. In the midst of Engendering themselves, feminist archaeologists seem to have missed the point of why gender is important to a feminist methodology. 
This seems particularly strange considering the place of gender archaeology within social archaeology, which has taken power relations as a focus. As Sarah Nelson points out, "agency asks not only 'who does it?' but also 'for whom is it done?'" (Nelson 1997: 74). Feminist archaeologists have yet to tackle either the degree to which or the mechanisms whereby women have been controlled by men, because of a wariness of creating a universality of women's subjugation. I am not suggesting this be reinstated, but rather that the relational aspect of control has been for too long ignored when considering gender.

\section{More Than Adding-and-Stirring Biology and Feminism}

Both feminism and evolutionary biology suggest a range of scenarios of control and resistance that do not aim to explain male and female roles but the relationship between men and women. Archaeology's involvement with individuals in a natural and social environment makes it ideal for sorting out the inconsistencies and similarities between feminism and evolutionary biology, because it can bridge the artificial gap between the biological and the cultural through a consideration of the way social information is transferred both through genes and through culture. We must move away from "reductionist postulations of ultimate causality: that reproductive experience is either 'culturally constructed' or 'biologically invariable"." (Sperling and Beyene 1997: 146). A feminist archaeology should use these sources for a closer investigation into the questions of power that an enquiry into gender involves. Feminist archaeologists should not shy away from asking questions about men's control over women in the past for fear of resurrecting a universal patriarchy, because this debate is of crucial importance both to feminists, and to the development of social archaeology.

\section{References}

Balme, J. and Beck, W. (eds.). 1995. Gendered Archaeology: The Second Australian Women in Archaeology Conference. Canberra: The Australian National University Publications.

Bender, B. 1989. The Roots of Inequality, in Miller, D., Rowland, M. and Tilley, C. (eds.). Domination and Resistance. London: Routledge: 83-95.

Butler, J. 1990. Gender Trouble: Feminism and the Subversion of Identity. London: Routledge.

Caplan, P. (ed.). 1987 The Cultural Construction of Sexuality. London: Tavistock.

Cixous, H. 1991. The Laugh of the Medusa, in Gunew, S. (ed.) A Reader in Feminist Knowledge. London: Routledge: 224-232.

Claassen, C. (ed.). 1992. Exploring Gender Through Archaeology. Selected Papers from the 1991 Boone Conference. Madison: Prehistory Press.

Claassen, C. (ed.). 1994. Women in Archaeology. Philadelphia: University of Philadelphia Press. 
Claassen, C. and Joyce, R. (eds.). 1997. Women in Prehistory. North America and Mesoamerica. Philadelphia: University of Pennsylvania Press:

Conkey, M. W. and Gero, J. 1997. Programme to Practice: Gender and Feminism in Archaeology. Annual Review of Anthropology 26: 411-37.

Conkey, M. W. and Tringham, R. E. 1995. Archaeology and the Goddess: Exploring the Contours of Feminist Archaeology, in Stanton, D. C. and Stewart, A. J. (eds.). Feminism's in the Academy. Michigan: University of Michigan Press: 199-248.

Conkey, M. W. and Tringham, R. E. 1996. Cultivating Thinking/Challenging Authority: Some Experiments in Feminist Pedagogy in Archaeology, in Wright, R. P. (ed.). Gender and Archaeology. Philadelphia: University of Pennsylvania Press: 224-250.

Coward, R. 1983. Patriarchal Precedents: Sexuality and Social Relations London: Routledge and Kegan Paul.

Daly, M. 1978. Gyn/Ecology: The Metaethics of Radical Feminism. Boston: Beacon Press:

Dobres, M. A. 1995. Beyond Gender Attribution: Some Methodological Issues for Engendering the Past, in Balme, J. and Beck, W. (eds.). Gendered Archaeology: The Second Australian Women in Archaeology Conference. Canberra: The Australian National University Publications: 51-67.

Du Cros, H. and Smith, L. (eds.). 1993. Women in Archaeology: A Feminist Critique. Canberra: The Australian National University.

Gero, J. and Conkey, M. (eds.). 1991. Engendering Archaeology: Women and Prehistory. Oxford: Basil Blackwell.

Gimbutas, M. 1982. The Goddesses and Gods of Old Europe. Berkeley: University of California Press.

Gimbutas, M. 1989. The Language of the Goddess. San Francisco: Harper and Row.

Gimbutas, M. 1991. The Civilization of the Goddess. San Francisco: Harper and Row.

Gowaty, P. A. 1992. Evolutionary Biology and Feminism. Human Nature 3 (3): 217 249.

Gowaty, P. A. 1997 Feminism and Evolutionary Biology: Boundaries, Intersections and Frontiers. New York: Chapman and Hall. 
Harvey, P. 1998. Feminism and Anthropology, in Jackson, S. and Jones, J. (eds.). Contemporary Feminist Theories. Edinburgh: Edinburgh University Press: 73-85.

Hill, E. 1998. Gender-Informed Archaeology: The Priority of Definition, the Use of Analogy, and the Multivariate Approach. The Journal of Archaeological Method and Theory 5 (1): 99-128.

Jaggar, A. M. 1983. Feminist Politics and Human Nature. Totowa, N.J.: Rowman and Allanheld.

Meskell, L. 1995. Goddesses, Gimbutas and 'New Age' Archaeology. Antiquity 69: 74-86.

Meskell, L. 1996 The Somatization of Archaeology. Norwegian Archaeological Review 29 (1): 1-16.

Moore, J. and Scott, E. (eds.). 1997. Invisible People and Processes: Writing Gender and Childhood into European Archaeology. London: Leicester University Press.

Nelson, S. M. 1998. Gender Hierarchies and the Queens of Silla, in Hays-Gilpin, K. and Whitley, D. S. (eds.). Reader in Gender Archaeology. London: Routledge, 319-335.

Nelson, S. M. 1997. Gender in Archaeology: Analysing Power and Prestige. London: Altamira Press.

Ortner, S. 1974. Is Female to Male as Nature is to Culture?, in Rosaldo, M. and Lamphere, L. (eds.). Women, Culture and Society. Stanford: Stanford University Press: 67-88.

Rosaldo, M. 1974. Women, Culture and Society: A Theoretical Overview, in Rosaldo, M. and Lamphere, L. (eds.). Women, Culture and Society. Stanford: Stanford University Press.

Sacks, K. 1979. Sisters and Wives: The Past and Future of Sexual Equality. London: Greenwood Press.

Sayers, J. 1982. Biological Roots: Feminism and Anti-Feminist Perspectives. London: Tavistock Publications.

Smuts, S. 1995. The Evolutionary Origins of Patriarchy. Human Nature 6 (1): 1-32.

Sperling, S. and Beyene, Y. 1997. A Pound of Biology and a Pinch of Culture or a Pinch of Biology and a Pound of Culture? The Necessity of Integrating Biology and Culture in Reproductive Strategies, in Hager, L.D. (ed.). Women in Evolution. London: Routledge: 137-153. 
Strathern, M. 1988. The Gender of the Gift. Berkeley: University of California Press.

Talalay, L. E. 1994. A Feminist Boomerang: The Greek Goddess of Greek Prehistory. Gender and History 6: 165-183.

Tong, R. 1989. Feminist Thought. A Comprehensive Introduction. London: Routledge.

Walde, D. and Willows, N. D. (eds.). 1991. The Archaeology of Gender: Proceedings of the $22^{\text {nd }}$ Annual Conference of the Archaeological Association of the University of Calgary. Calgary: University of Calgary Archaeological Association.

Watson, P. J. and Kennedy, M. C. 1998. The Development of Horticulture in the Eastern Woodlands of North America: Women's Role; in Hays-Gilin, K. and Whitley, D. S. (eds.). Archaeological Approaches to the Study of Gender. London: Routledge: 173-190.

Wylie, A. 1997. Good Science, Bad Science, or Science as Usual? Feminist Critiques of Science, in Hager, L.D. (ed.). Women in Evolution. London: Routledge: 29-55.

Wright, R. (ed.). 1996. Gender and Archaeology. Philadelphia: University of Pennsylvania Press.

Yates, T. 1993. Frameworks for an Archaeology of the Body, in Tilley, C. (ed.). Interpretative Archaeology. Oxford: Berg: 31-73. 